\title{
Access to Justice: Dynamic, Foundational, and Generative
}

\section{GIANLUIGI PALOMBELLA}

Abstract. Access to justice reveals its contours through, and is best understood for, its dynamic nature. Conceptually, it shows a number of peculiar oscillations within couplets of opposites, like rights and structure, autonomous and derivative right, and substance and procedure. What does make for its foundational nature, and how does the latter differ from and coexist with access as a fundamental right? It belongs to the requirements of the rule of law and plays a foundational role towards legality, beyond being counted among the most fundamental rights. Despite its apparent procedural character, it has a substantive value, as well as a peculiar "generative" function. The article enquires into these conceptual features by looking at the ways through which access to justice is provided in the main European and international legal documents, as well as at its progress under judicial interpretation.

1. Access to justice is often seen as a fundamental right, featuring among the most relevant achievements in contemporary constitutional provisions as well as in the European normative settings both through the Charter of Fundamental Rights of the European Union (CFR) and in the European Convention on Human Rights (ECHR). It has mainly been the focus of studies on procedural law, where it reveals a range of implications worthy of deeper reflection in varied substantive legal domains as well. The notion itself has been an object of contention among a number of alternative conceptions, whether substantive or procedural, a right or a structural feature of law, an instrumental or inherent value, a core or derivative right. All of these alternatives imply diverse practical consequences in allowing or limiting access to justice. However, going through those diverse ideas concerning the protection (or denial) of access is not only instructive per se, but helps bring to the forefront its more stable traits, its present "nature" as well as the role that access to justice plays in the current transformations of law. Accordingly, access to justice appears to exceed the "normal" view as a fundamental right because — as I shall submit—it is, beyond that, a "foundational" condition/right, a condicio sine qua non of legality as such.

However, access does not play the static function of any other building block in the legal edifice. Although at times unexpected or unnoticed, access to justice evolves through cases and circumstances, and its transformative semblances are witnessing its very remarkable dynamic core. Finally, the dynamic power of access reaches to a further and unique capacity that should be called generative: The procedural structure of access is not just serving pre-existing substantive rights, granting them effective remedies, but it can help structure novel rights and open new scenarios of legal protection. The three aforementioned features of the notion of access can be illustrated 
by paying attention to the interplay between conceptual understanding and practical uses in legal realities.

Although the right of access to justice is most often considered an absolute, its contents and contours need to be written again and again. What makes for it in real practice is a complex assessment to be constantly updated. As Cancado Trindade (2011, 77) has noted, "[v]irtually all existing mechanisms of international protection have been conceived and adopted as responses to different kinds of human rights violations. As new needs of protection arise, new responses are needed." Both access to justice and its protection accordingly bear a dynamic nature, whose scope and fabric are to be defined with a view to increasing the chances of concrete implementation. That is why for a long time sociolegal analyses have often undertaken legal enquiries on access to justice: Conditions of factual deprivation of rights, as well as obstacles against standing before a court, are brought into legal analysis as part of the monitoring the evolution of access to justice (Cappelletti and Garth 1978).

It is appropriate to understand access to justice, first of all, through such a dynamic conception, one that approaches rights from their normative angle: In that vein, as Joseph Raz wrote, we recognize a right as the reason for a range of evolutionary protections or implementations that cannot be entirely fixed in advance: "the implications of a right, such as the right to education, and the duties it grounds, depend on additional premises and these cannot in principle be wholly determined in advance. [...] there may be future circumstances which [...] give rise to a new duty which was not predicted in advance. Even if no such duty is unpredictable, the total implications of the right to education are in principle unpredictable. Because of this, rights can be ascribed a dynamic character" (Raz 1986, 185).

The complexity of access to justice cannot be overstated, even if seen simply through its known and "predictable" ingredients. The sheer right to a judge is a necessary part of it, and it carries a well-known, iconic strength, but that would not give us enough to go on: The fairness of the procedure or the effectivity or availability of concrete remedies are of equal relevance. Any of these are segments, drawing the line of access to justice. They can end up undermining it, and making it an empty ritual. This is why a right to effective remedy or to a fair trial has become essential to it.

On the "formal" side, some normative pillars work as reference points and reflect the composite fabric of access. From the Magna Carta Libertatum access to justice runs all the way to the Universal Declaration of Human Rights (Arts. 8 and 10), the UN International Covenant on Civil and Political Rights (ICCPR) (Arts. 2(3) and 14), and a great number of national, regional, and international documents. ${ }^{1}$ In European human rights law, Article 13 of the European Convention on Human Rights (ECHR) guarantees a right to an effective remedy, and Article 6 a right to a fair trial; in the section concerning justice, the European Charter of Fundamental Rights (CFR)

1 For example, the 1998 Aarhus Convention on Access to Information, Public Participation in Decision-Making and Access to Justice in Environmental Matters and the 2006 Convention on the Rights of Persons with Disabilities, just to mention a couple. 
protects access to a fair trial and to an effective remedy at Article $47 .{ }^{2}$ It is fair to say that general requirements, from equality before a court to courts' impartiality and independence, ${ }^{3}$ from substantive redress and effective remedy to the fairness of the procedure, have been substantiated through judicial interpretation. However, they are complemented by additional rules provided in different legal areas. Importantly, the production of new legislation has enriched and better determined what access to justice would entail in specific fields of action. A case in point is the Aarhus Convention, insofar as it enables access to justice by way of constructing the architecture of access to information and participation in environmental matters.

Again, the ongoing process of applying norms has enriched the literal meaning of those rules, defining their interpretive scope, often on a reasonable case-by-case basis. The dynamic character of access to justice might be seen both as a result of the transformations of the substantive rights for which access to justice is claimed and as the consequence of the open-ended nature of "access," a word that, as noted above, inevitably refers to the variety of components and conditions that are to be considered for it to be achieved.

2. Access to justice speaks to the conditions of legality in its basic quality. Unsurprisingly, it has not just a fundamental character whatsoever, but bears a foundational nature

First of all, it is held to inhere in the ideal of the rule of law. It features among the general requirements that are numbered as essential to the rule of law by those accounts of the latter that are aptly defined morphological or anatomical (Krygier 2009). According to Raz's "virtue of the rule of law," the infringement of human rights would not displace the rule of law, since they are not in themselves essential to the definition of the rule of law he provides. Nonetheless, "the principles of natural justice must be observed" (Raz 1979, 217, and also 216-7). ${ }^{4}$ Thus, among the latter "open and fair hearing, absence of bias, and the like" are themselves necessary in order to fulfil the primary raison d'etre of law, that is, to guide behaviour: Therefore, guarantees of access to justice should be considered among those that "are obviously essential for the correct application of the law and thus, through the very same considerations mentioned above, to its ability to guide action" (ibid.). The capacity of law to guide action is at the basis of the independence of the judiciary as well (in order "to apply the law correctly") (ibid.). Access to justice serves nothing other than the law itself. Its structural belonging to the still thin notion of the rule of law in Raz's

\footnotetext{
2 Article 47: "Right to an Effective Remedy and to a Fair Trial: Everyone whose rights and freedoms guaranteed by the law of the Union are violated has the right to ineffective remedy before a tribunal in compliance with the conditions laid down in this Article. Everyone is entitled to a fair and public hearing within a reasonable time by an independent and impartial tribunal previously established by law. Everyone shall have the possibility of being advised, defended and represented. Legal aid shall be made available to those who lack sufficient resources in so far as such aid is necessary to ensure effective access to justice." Notably, under Article 53, the rights enshrined in the Charter are given the same meaning and scope as the corresponding ones laid down in the ECHR.

3 The conceptual underpinning of each is also spelled out by the CJEU in the recent judgment of the Court (Grand Chamber) of 25 July 2018, Minister for Justice and Equality (Deficiencies in the System of Justice), Case C-216/18 PPU, ECLI:EU:C:2018:586, esp. pars. 63-7.

4 Raz $(1979,214-19)$ lists a number of requirements that all derive from the two principles according to which citizens must be guided by and obey the law, and that it must be possible to obey the law.
} 
terms brings out an even finer feature, that is, the basic quality of surviving the contingent content of law itself. Insofar as human rights are only in part (i.e., only within the sphere of natural justice requirements) deemed conceptually constitutive of law, access to justice differs from them. The same holds for democracy: Its fading away would not necessarily imply the collapse of law (Palombella 2018). Contrariwise, the point of access to justice is of higher import: The loss of access to justice entails the loss of legality. Its foundational role stands, even regardless of its current presentation as a fundamental right. Again, since any social system governed by law cannot do without it, access to justice proves to be at the cleavage between law and lawlessness.

In this regard, the modern legal thought sheds its light on access to justice, insofar as it focuses upon the birth of law from a state of nature. In a sense, access to justice retains the features of the enlightening Kantian idea of law's raison d'étre. In Kant's reasoning, a legal society is a condition of conceivability of justice, and law and justice are resorted to conceptually in order to avoid and leave a lawless state, a "condition that is not rightful," since the abuse of personal liberty and dependence upon external control are in such a state unobjectionable. ${ }^{5}$ The institution of a civil society is connected to the fact of law and, as it seems, it basically makes for access to justice and turns out to be coincidental with it, too.

Much of the effort leading to a civil state is seen as affording the chance to access justice, for some justice to be delivered. Accordingly, more than being a fundamental right in any legal sense, access to justice was better meant as different from, say, the Kantian-only natural right, the right to liberty. It clearly proves to be not just a fundamental right (among others), not just the human rights that we owe to human beings, but a foundational right, marking the birth of (positive) law as such: It separates violence from law, and in this sense it is a right to be ordered by law, abandoning a state that by nature Kant defines as "devoid of justice."

Needless to say, if seen under this perspective, the "foundational" character of access to justice is a right only in a spurious sense, or better said, it epistemically belongs to the structure of law, regardless of whether it is going to be seen also as an individual right of its own. It is not foundational because it is a "right": It is foundational because it makes law possible. As in the foregoing, seen from the Kantian reading, it is not a natural right: Rather, it makes for the shift from nature to civil society, and such a shift is not a right but a duty.

As a right, it should possibly be a legal right ${ }^{6}$ or in principle something that becomes conceivable as a consequence of law. Accordingly, access to justice bears a double profile: As a right it is to be determined by laws, but by virtue of its belonging in justice it is part of the structuration of legality, thereby bearing a foundational nature.

3. An ambivalent nature of access to justice is not just of philosophical interest in the abstract: Being inherent in the rule of law, belonging in the structure of a legal order, or being a right can make a difference, can play a mixed or complementary role, for example in instituting or "activating" the functioning of a legal order. In the complex

${ }^{5}$ Kant 1996, § 42, p. 86 (AA 6:307); cf. § 44, p. 90 (AA 6:312): For that reason, man "ought above all else to enter a civil condition," and accordingly "each may impel the other by force to leave this state and enter into a rightful condition."

${ }^{6}$ On the meaning of that term see, famously, Hart 1982. 
and "multilevel" environment of the European Union we can find a proper instance of such a role played by access. As is known, European Union regulations have direct effect within the member states' legal orders, and the latter have a duty to implement the directives issued by the Union. The European Union's entire legal order-one that is based on the rule of law-would nonetheless be rather elusive, if not ineffective, should the relations among the two levels—-the EU and the member states-be lacking a double device that puts in pride of place the judicial power to decide by directly referring to EU law, even when issues are raised before national courts. On one side, "preliminary reference" (Art. 267 TEU, short for Treaty on European Union) works by requiring national courts to turn to the European Court of Justice (ECJ or CJEU) for matters of EU law interpretation and application; on the other side, and more importantly here, citizens are allowed to sue their own state for damages caused by the infringement of EU law. This is the Francovich rule, ${ }^{7}$ authored by the ECJ only in 1991. What the "rule" does, in truth, is grant access to justice as a matter necessarily connected to the existence of the European legal order: In the words of the Court of Justice, nationals of member states are part of the integrated legal system of the EU and member states. ${ }^{8}$ Accordingly, "[t]he full effectiveness of Community rules would be impaired and the protection of the rights which they grant would be weakened if individuals were unable to obtain redress when their rights are infringed by a breach of Community law for which a Member State can be held responsible" (Francovich, par. 33). Placing citizens as direct players in vindicating the EU legal order vis-à-vis their own state is the genius of the matter, evidently because the move bridges a gap in the functioning of the EU legal order, this by connecting it to the delivery of justice that should flow from a "true" legal order. The role of access to justice is defined at the crossroads between the two legal orders, and it turns out to be the only trigger for the Community legal order to be actually effective: Access to justice, that is, "the possibility of obtaining redress from the Member State[,] is particularly indispensable where, as in this case, the full effectiveness of Community rules is subject to prior action on the part of the State and where, consequently, in the absence of such action, individuals cannot enforce before the national courts the rights conferred upon them by Community law" (Francovich, par. 34). In that connection in a later decision, the Court of Justice recognized legal aid to legal persons in order to challenge the state for belated implementation of a directive, basing its decision explicitly on the right of access to justice, that is, "the right of a legal person to effective access to justice and, accordingly, in the context of EU law, [...] the principle of effective judicial protection. ${ }^{\prime \prime}$

In truth, access comes to the forefront when the need arises to reaffirm the unitary structure of the "multilevel" EU and of its judicial resources, whether provided by the member states or by the Court of Justice: Article 19(1) TEU states that "Member States shall provide remedies sufficient to ensure effective legal protection

\footnotetext{
7 Judgment of 19 November 1991, Francovich and Bonifaci v Italian Republic, Joined Cases C-6/90 and C-9/90 (ECR I-5375), ECLI:EU:C:1991:428 (Francovich for short).

8 See Judgment of 5 February 1963, Van Gend en Loos, Case 26/62 (ECR 1), ECLI:EU:C:1963:1, and judgment of 15 July 1964, Costa v ENEL, Case 6-64 (ECR 585), ECLI:EU:C:1964:66.

9 Judgment of the Court (Second Chamber) of 22 December 2010, DEB Deutsche Energiehandelsund Beratungsgesellschaft mbH v Bundesrepublik Deutschland, Case C-279/09 (ECR I-13849), ECLI:EU:C:2010:811, par. 29.
} 
in the fields covered by Union law." By a recent decision, Portuguese Judges (2018), the CJEU resorts to the rule-of-law-based structure of the complex order of the European Union in order to defend judicial independence and access to justice as effective legal protection. ${ }^{10}$ Insofar as the national judiciary is entrusted with the application of Union law, it partakes in the European judicial system as a whole, and to them requirements of independence, fairness, and effective judicial protection do apply as a matter of European law under the oversight of the CJEU. That statement is of value also as regards the proper functioning of the European access-to-justice system, and with reference to the aforementioned availability of national remedies vis-à-vis states' noncompliance with European rules, directives included. Ultimately, the same holds true for the other European prong, the preliminary reference, in order for it to correctly function: According to the Court, "the independence of national courts and tribunals is, in particular, essential to the proper working of the judicial cooperation system embodied by the preliminary ruling mechanism under Article 267 TFEU, in that [...] that mechanism may be activated only by a body responsible for applying EU law which satisfies, inter alia, that criterion of independence" (Portuguese Judges, par. 43).

Of course, justifying access to justice as a right or as a structure of the legal order and even of the governmental system may well bring about different consequences. In the years when detainees at Guantanamo Bay were denied access to justice, at some point in the tussle between the Supreme Court of the United States, the Bush administration, and Congress, ${ }^{11}$ access to justice-in the form of habeas corpusbecame, possibly, just a right of the (American) individual citizen, and as a constitutional right it was to be denied to aliens. For that very reason, at the United States Court of Appeals for the District of Columbia Circuit, the dissenting opinion of Judge Rogers, in an attempt to support habeas corpus, defined it as a structural feature of the legal system: "Far from conferring an individual right that might pertain only to persons substantially connected to the United States, [...] the Suspension Clause [US Const., Art. I, § 9, cl. 2: 'The privilege of the writ of habeas corpus shall not be suspended, unless when in cases of rebellion or invasion the public safety may require it.'] is a limitation on the powers of Congress."12 Even when, eventually, the Supreme

10 The Court does so by reconnecting the various components of the European system: "The principle of the effective judicial protection of individuals' rights under EU law, referred to in the second subparagraph of Article 19(1) TEU, is a general principle of EU law stemming from the constitutional traditions common to the Member States, which has been enshrined in Articles 6 and 13 of the European Convention for the Protection of Human Rights and Fundamental Freedoms, [...] and which is now reaffirmed by Article 47 of the Charter [i.e., the EU Charter of Fundamental Rights]." Judgment of the Court (Grand Chamber) of 27 February 2018, Associação Sindical dos Juízes Portugueses v Tribunal de Contas, Case C-64/16, ECLI:EU:C:2018:117 (Portuguese Judges for short), par. 35.

11 The Military Commissions Act of October 17, 2006, overruled the decision of the Supreme Court in Rasul v. Bush, 542 U.S. 466 (2004), thereby eliminating habeas corpus for aliens. As a consequence of the Military Commissions Act, judges in the US Court of Appeals dismissed the pending habeas petitions of tens of Guantanamo detainees.

${ }_{12}$ United States Court of Appeals for the District of Columbia Circuit, Boumediene v. Bush, 476 F.3d 981, 995 (D.C. Cir. 2007). Of course, the idea of human rights falls completely outside the discourse of the courts. 
Court in Boumediene v. Bush ${ }^{13}$ confirmed habeas corpus to be a right, it stressed that the framers of the Constitution were motivated by an "inherent distrust of governmental power" and therefore wrote that the writ, i.e., the Suspension Clause, protects the "separation of powers" by "ensur[ing] that, except during periods of formal suspension, the Judiciary will have a time-tested device, the writ, to maintain the delicate balance of governance that is itself the surest safeguard of liberty."14

4. There is an opposite side of the coin, though. In order to be defended, access to justice must in other cases appear as a fundamental right, instead of a rule of law or structural requirement. The Court of Justice of the European Union (CJEU) decided a milestone case in 2008, asking for hearing requirements in the UN Security Council terrorist asset freeze regime. However, it did so not on some rule-of-law grounds, but because the UN regime departed from judicial protection as the basic opportunity to defend individual rights. The Kadi case can well be framed as concerning the denial of the right to a judge and to a defence (along with the right to property). The European Court of First Instance (CFI) had held that the resolutions of the Security Council placing Mr. Kadi in the blacklist of Al Qaeda affiliates and therefore requiring the EU to freeze his assets without allowing for a right of defence and access to justice, fall "outside the ambit of the Court's judicial review."15 Thus, it was the rule of international law, given its supremacy over any other states' obligations (pursuant to Art. 103 UN Charter), to deny the expected protection of Kadi's rights. Later on, the (then) European Court of Justice ${ }^{16}$ found that Kadi's fundamental rights had been infringed by the EU regulation implementing the Security Council resolution against him.

In the end, according to the ECJ, access to justice seems of so high an importance within European primary law that internal regulations against it are unlawful, regardless of any Security Council mandate. One could say that access to justice was, as a matter of fact, also an argument for European primary law to consequently prevail over the obligations stemming from international law (thereby disregarding Art. 103 UN Charter). ${ }^{17}$

It is, in fact, rather decisive that when it resonates both as an individual right and as a rule-of-law requirement, access to justice displays its foundational character, being premised on respect for a legal order as a whole. Beyond the relevance of the substantive claims to regain rights in the Kadi case, the issue at stake was also centred

13 United States Supreme Court, Boumediene v. Bush, 553 U.S. 723 (2008). See also the SCOTUSblog commentary at https://www.scotusblog.com/case-files/cases/boumedieneal-odah-v-bush/. 14 Boumediene v. Bush, 553 U.S. 723, 725 (2008).

15 Judgment of the CFI of 21 September 2005, Yassin Abdullah Kadi v Council of the European Union and Commission of the European Communities, Case T-315/01 (ECR II-3649), ECLI:EU:T:2005:332, par. 225.

16 Judgment of the Court (Grand Chamber) of 3 September 2008, Yassin Abdullah Kadi and Al Barakaat International Foundation $\mathrm{v}$ Council of the European Union and Commission of the European Communities, Joined Cases C-402/05 P and C-415/05 P (ECR I-6351), ECLI:EU:C:2008:461.

17 Scholarly comments were either criticising the Court's failure to comply with the rule of (international) law or praising its defence of access to justice. In truth, the reasoning of the Court missed an opportunity to admit that instead of a matter simply concerning an EU internal regulation, the question was clearly exposing a failure of the international system, and specifically the Security Council system, to conform to the basic human rights recognised by international law itself, for which access to justice is of the highest prominence. 
upon whether any external international public interest could be taken as displacing domestic norms enshrining access to justice.

Some further relevance, in this regard, is borne by another important decision concerning access to civil compensation in the Italian proceedings against the German government. A case had been brought in 2012 before the International Court of Justice $(\mathrm{ICJ})^{18}$ by Germany claiming that Italy had failed to respect state immunity by allowing civil claims to compensation before Italian courts in respect of crimes committed by German military personnel during the Second World War. The ICJ declared that the violation of jus cogens norms by Germany does not displace its right to immunity, since the latter is endowed with logical priority, on a procedural plane, and prevents any further judgment on the merits by domestic courts. Moreover, the Court ascertained that a customary rule does exist granting state immunity for acta jure imperii, to which cases of grave war crimes do not provide an exception, and notwithstanding the absence of any other means of redress. When the question reached the Italian Constitutional Court ${ }^{19}$ in 2014, the latter held that, despite the Article 94 UN Charter obligation to comply with the decisions of the ICJ, the customary-international-law rule of state immunity never "entered" the Italian legal order because, Article 10 of the Italian Constitution notwithstanding ("The Italian legal system conforms to the generally recognized principles of international law"), a counter-limit is imposed by the supreme constitutional principles found in Articles 2 and 24 of the Constitution, guaranteeing human rights and access to justice. As a consequence, legislation implementing the ICJ decision in Germany v. Italy was declared unconstitutional. ${ }^{20}$

Access to justice was therefore a casus belli between two legal orders. However, differently from the ECJ in the Kadi case, the Court considered in depth the normative strength of the ICJ assessment of the primacy of states' immunity, and carefully reasoned, on the limen between the two legal orders, balancing between the principle of states' equality, immunity, and the right of access to justice in the circumstances of the case. $^{21}$

What we can learn from both cases concerns, first of all, the autonomy of the right of access to justice as a core right. The two values, in fact opposing access to justice, have been in the one case security and international peace (in the fight against terrorism) and in the other case the customary law on states' immunity. When facing the problem of access to justice, the absence of any procedural guarantees for the defendants before the Sanctions Committee of the Security Council seems to undermine its very authority, and make its action look lawless and arbitrary. The claim from the Italian Constitutional Court that states' immunity would not be compatible with primary constitutional principles_-if immunity covers crimes against humanity and the

18 ICJ, Jurisdictional Immunities of the State (Germany v. Italy: Greece Intervening), judgment, ICJ Reports, p. 99 (3 February 2012), available at https:/ /www.icj-cij.org/en/case/143/judgments. 19 Italian Constitutional Court, judgment no. 238 of 22 October 2014, ECLI:IT:COST:2014:238, available at http://www.cortecostituzionale.it/documenti/download/doc/recent_judgm ents/S238_2013_en.pdf.

20 For a more complete account and comment on the case see Palombella 2016, and for a wider theoretical frame see Palombella 2019a.

21 Also part of the balancing are the principles underlying jus cogens norms, which are countervailing parameters that are found both as part of international law and as domestic "constitutionalized" commitments. These jus cogens commitments work as a bridge between the two normative orders. 
violation of jus cogens norms- has a twofold lesson to teach. According to the Italian court, immunity cannot hold especially when no remedies and no other fora would be available to the victims. Accepting immunity in such cases of grave crimes would be equivalent to accepting the wearing away of international rule of law, which the Italian constitution committed to, and to making the interstate setting a lawless land. The protection of access to justice has, in fact, forced European and Italian courts to find their own way to circumvent the dogma of hierarchy, but has also paved the way to the implicit statement that legality devoid of access to justice ends up missing its basic reference to justice itself.

As things stand, access to justice gains its value, through such episodes, because its "autonomy" is defended also as a matter of more fundamental importance than other norms and principles protected by the primary law of the EU or the Italian Constitution. One could dare to say that the arguments from the ECJ, as much as those of the Constitutional Court, were not to be understood merely as gatekeeping, that is, as defending idiosyncratic and supreme beliefs proper to the European or the Italian legal order, and not just a retreat to identity-based reasons against external and international law primacy. The further underlying sense of their reasoning can well be hinting at the largely sharable conviction that both the Security Council and the ICJ were undermining the fundamental premises of legality to which they have all subscribed. They were all in some way referring to the assumption that access to justice is not just one fundamental right among others but is rather a foundational right, in the absence of which the entire edifice of legal civilization falls apart.

Accordingly, at issue is what I would call the dual nature of access to justice. That is due to multiple reasons: On the one hand, as I believe, its foundational nature-as a structural requirement for law and the chance of justice-lives along with its alleged nature as a fundamental right of individual persons. On the other hand, as we shall see in the following, a second reason for its dual character concerns its essentialist or derivative nature, and a third the justification of the right itself, whether on the basis of the public or individual interest.

5. Access to justice is most often understood as a fundamental right. It is, however, useful to recount at least some of the main oscillations concerning its use and notion. The right may well be serving the protection of other rights, but at the same time it is endowed with ultimate value: From the latter perspective access to justice is held to be a right of its own. What the protection of access to justice stands for is often held to be human dignity, as it features in Article 1 of the European Charter of Fundamental Rights (Jones 2012). That is a consequence of justice understood as a necessary protection of personal dignity. In the well-known theory of Lon Fuller (1969), for example, requirements of legality basically work against arbitrary power and thereby prevent the offence to the dignity of human beings as responsible agents. Beyond European judicial findings, in a leading case the US Supreme Court defended the right to be heard, obviously concerning effectivity and fairness of access to justice, not on the basis of some other substantive constitutional right, but as a means of recognition of human dignity. ${ }^{22}$ This paves the way for an essentialist conception of the right of access to justice. 
However, as may hold in general for procedural rights, case law, as with the European Union, alternates instrumental arguments (valuing access to justice as a matter of community interest) with essentialist ones. In the latter case, e.g., by stressing that procedural participation should be granted even when in a specific context that would not be contributing at all to either gaining further information or advancing towards truth and the public interest. On the other hand, as in the case of administrative procedures, access to hearing or to be informed about evidence against us, is upheld as instrumental to the public side, not just serving individual interest (Barbier de la Serre 2006).

A closely connected issue concerns the right itself, whether autonomous, selfstanding, or whether it serves the substantive right which is the ground of justice (and therefore the ground of access). For example, "the right of every person to be heard, before any individual measure which would affect him or her adversely is taken" is listed as a component of a preeminent right to good administration in Article 41 of the Charter of Fundamental Rights of the European Union.

A derivative right would depend on the interest or value that another, substantive, not procedural, right protects: The derivative right would then be subordinate to the ultimate value, say, of (defending) the right to liberty, or property, or life, and so forth..$^{23}$

Surely, the most typical relations between procedural and substantive rights do allow for a derivative construction of access to justice; in such a case, the substantive right is determinative for the issue at stake. For instance, the right to know, essential informative basis partaking in (the viability of) access to justice, might be superseded in an easier way if it were intended to serve a substantive right (for example, to property) that is taken to be of lower weight vis-à-vis countervailing interests and rights (think of interests concerning, e.g., industrial secrets or environmental policies). Courts can describe a right as a core or derivative right depending on the fundamental interests that are taken to justify it and those that are going to be prioritised in given circumstances. ${ }^{24}$

As Francesco Francioni has pointed out, although worthy of legal protection, access to justice is construed in the main human rights treaties more as a procedural guarantee, dependent on other substantive rights and on their protection, than as a human right, in a core, and unrestricted, sense of its generalised value: Article 47 CFR creates "a right of access to justice only for the situations where the rights and freedoms guaranteed in the Charter have been violated by the European Union's institutions" (Francioni 2007, 32). In a similar vein, Article 13 ECHR (the right to an effective remedy) does not allow for judicial protection as such, but does so only with reference to the rights enshrined in the Convention, which, albeit largely expanded since the 1950s, do not include economic or social rights or any other guarantees for rights outside the scope of the Convention itself. ${ }^{25}$ However, Francioni shows, thereafter, that as a matter of judicial reasoning, courts tend to expand the right of access to

23 On a right's instrumental or ultimate value right see, for example, Raz 1986, 192.

${ }^{24}$ As to the right to know, they accordingly can decide between nondisclosure and disclosure (see Roesler 2012).

25 A better and "broader" basis of access to justice is contained in Articles 8 and 25 of the American Convention on Human Rights (1969), including fundamental rights recognised by the state concerned (see Francioni 2007, 32). 
justice and make less clear-cut the distinction between this right as a core right and the same right as a consequential one.

All in all, if access to justice is to be given a convenient safeguard, its "autonomy" should not be challenged. The dignitary or associative basis for such autonomy has been set out for some time now, in American constitutional law as well, for example (Michelman 1977; Summers 1974). As is commonly noted, to torture someone is wrong and illegal, even if it should prove useful in ascertaining facts and the truth, and even regardless of the argument stressing the unreliability of the information that could by that method be gained. Having a right to a defence protects individual autonomy, and in general being worthy of a just, or due, process of law serves the individual interest in not being unjustly convicted, one that would retain its value, even if the connected further substantive right could not be salvaged.

Furthermore, the relevance of access to justice as a "core" right can be inferred through judicial interpretation, when courts expand the right beyond its textual scope. Famously, in the Golder case a detainee had been barred from consulting a lawyer to sue his accuser: ${ }^{26}$ At the European Court of Human Rights (ECtHR) the UK argued that Article 6 was not thereby infringed, since it encompasses only the right to a fair trial, that is, to the fairness and due process requirements, a right that holds only when a proceeding is started: Accordingly, it is not a right to start and access the proceeding itself. Beyond the text the Court referred to the rule of law and to legal European traditions to infer-from Article 6 ECHR—a wider and self-standing sense of access to justice, including to legal aid.

6. The very right to an effective remedy has been traditionally stressed as essential to and implied by the content of access to justice. Again, it is easy to understand that emptying access to justice of its full-fledged effectivity, is simply tantamount to whittling away at the law, not just to undermining an individual, albeit fundamental, right. The distinction might be rather nuanced, but it suggests that while the disregard of some human right by a legal order might make its record at odds with international law obligations, or might expose the authoritarian, conservative, or discriminatory features of its legal culture, the denial of access to justice revokes the legal status of the normative structures that are in place, and the wider such a denial, the deeper the undermining of the legal order, as a whole.

Access to justice, however, can face varied forms of indirect denial (not formally foreclosing access), that is, being undermined through oblique routes. One typology of relevance concerns, in fact, the requirement of judicial independence.

Belonging to the oft-mentioned natural justice requirements, judicial independence partakes in granting access to (sound) justice. It is a premise to the Article 47 CFR provision, providing for effective remedy. An expedient strategy to drain and empty access to justice, by circumventing its core sense, without denying formal

26 He found himself unable to sue a warden of his prison for defamation, for lack of authorization to consult a lawyer, to be granted by the interior minister. Golder v. United Kingdom, App. No. 4451/70 [1975] ECHR 1 (21 February 1975). 
access to a judge, seeks to undermine the functional substance through submitting the judiciary or parts of it to political bias and whim. Imposing governmental directives on judicial decision-making firstly weakens the rule of law and inevitably deprives access to justice of its raison d'être. Recent examples, like Hungarian or Polish legislation (Halmai 2017) ${ }^{27}$ modifying the retirement age of members of the judiciary, and recurrent subsequent acts reducing the freedom of judges to protect constitutional rights are cases in point. The importance of judicial independence, of access to fair and effective justice, concerns the CJEU as an essential requirement: In a recent preliminary ruling, the Court stated that the European arrest warrant can be suspended if the executing judicial authority has substantial grounds, all things considered, for believing that the person involved would run the risk of breach of her "fundamental right to a fair trial guaranteed by the second paragraph of Article 47 of the Charter, on account of systemic or generalised deficiencies so far as concerns the independence of the issuing Member State's judiciary." ${ }^{28}$ In other words, it holds true that, should the independence of the judiciary be undermined in Poland, the very basis of mutual trust, premised on the European arrest warrant, would be in jeopardy. That is so because the right to a fair trial is "a right which is of cardinal importance as a guarantee that all the rights which individuals derive from EU law will be protected and that the values common to the Member States set out in Article 2 TEU, in particular the value of the rule of law, will be safeguarded" (Minister for Justice, par. 48).

It is to be noted that the event of political power coming into conflict with the judiciary is not, in itself, rare. But systemic enquiry into the general context can tell us whether access to justice is substantively in danger. The famous court packing that President Roosevelt was on the point of finalizing, in order for his New Deal legislation to be granted a viable judgement of constitutional conformity by the Supreme Court, reflects such a tension between the executive and the judiciary. Indeed, the point to be made is not about how conservative a court might have been in rejecting the desiderata of executive power (be it Polish, Hungarian, or American), but how free and "independent" from such power the delivery of justice is (or is going to be). Access to justice, and judicial independence as part of it, is not so much a question of whether a court pursues a progressive or a conservative agenda, as it is a question of which legal guarantees are in place for justice to be effectively claimed by and impartially delivered to citizens.

As a rule-of-law issue, the more access to justice is safeguarded, as a matter of the independence of the judiciary, the less it is subordinate to serving governmental policies, and to the contingent will to weaken or strengthen substantive rights. This means, in the end, that the autonomy of access to justice vis-à-vis substantive rights

27 On June 24, 2019, the CJEU decided that Poland had violated EU law by forcing judges into early retirement. However, Poland had already reinstated the judges after protests and international pressure. See Judgment of the Court (Grand Chamber) of 24 June 2019, European Commission v Republic of Poland, Case C-619/18, ECLI:EU:C:2019:531. See also "European Commission Statement on the Judgment of the European Court of Justice on Poland's Supreme Court Law," Brussels, June 24, 2019, http://europa.eu/rapid/press-release_STATE MENT-19-3376_en.htm.

28 Judgment of the Court (Grand Chamber) of 25 July 2018, Minister for Justice and Equality (Deficiencies in the System of Justice), Case C-216/18 PPU, ECLI:EU:C:2018:586 (Minister for Justice for short), par. 79 . 
or public-interest directives is of the highest value, among other reasons because it can often work in favour of the rule of law: It can do so by safeguarding what I call jurisdictio-related guarantees vis-à-vis programmes of the public weal decided by the sovereign power. All of them are essential to a sound and effective protection of liberty from the monopoly of law in the hands of the most powerful, as the ultimate objective of the rule-of-law ideal (Palombella 2019b).

7. There is at least a further aspect related to the autonomy of access to justice that should be given pride of place. I believe it can better be explained by reference to the rising tide of environmental litigation, which has become a flourishing field of legal innovation.

In the case of justiciability of environmental rights and interests of the people, it seems that a virtuous circle is triggered whereby achieving access to justice fosters understanding, clarification, and possibly the recognition of rights previously perceived more as principles of good behaviour for governments, including legislators, than as individual rights providing the ground to have standing before a court.

The EU is committed to granting access to justice, even in such matters, also by ratifying the Aarhus Convention in 2005. But the pivotal question remains, regarding how to improve access by reducing the impediments for private entities to bring actions to court: lack of standing, that is, the right of NGOs or individuals to gain direct access to courts against EU acts (or national acts failing to comply with EU directives and regulations) impacting on the environment or public health. The CJEU interprets the standing requirements on the basis of Article 263(4) TEU (Treaty on the Functioning of the European Union) (Schoukens 2015), ${ }^{29}$ and it seems to adhere to the so-called Plaumann doctrine: In relation to environmental legal standing, the doctrine results in barring NGOs from courts since they cannot be considered individually affected by environmental measures (see Krämer 2015). On the member-states side, though, the CJEU is instead largely progressive: In the Protect case (2017), ${ }^{30}$ brought by the referring Austrian court, the CJEU ruled that environmental NGOs have access to justice in water law proceedings and must be able to contest a permit for water uses that may run contrary to the obligation provided by the EU's Water Framework Directive to prevent the deterioration of water resources. ${ }^{31}$ The Court held that all environmental law must be applied in conformity with the Aarhus Convention by national courts, so as to allow NGO participation. Another matter, however, is whether such standing can extend to individuals, as per Articles 9(3) and 2(5) of the Aarhus Convention.

As I wish to submit, the role played by access to justice in the evolution of environmental issues is testament to a peculiar and insufficiently noticed function:

29 Article 263(4) of the Treaty reads as follows: "Any natural or legal person may, under the conditions laid down in the first and second paragraphs, institute proceedings against an act addressed to that person or which is of direct and individual concern to them, and against a regulatory act which is of direct concern to them and does not entail implementing measures." 30 Judgment of the Court (Second Chamber) of 20 December 2017, Protect Natur-, Arten- und Landschaftsschutz Umweltorganisation $\mathrm{v}$ Bezirkshauptmannschaft Gmünd, request for a preliminary ruling from the Verwaltungsgerichtshof (Supreme Administrative Court of Austria), Case C664/15, ECLI:EU:C:2017:987.

31 Notably, this holds outside the scope of Environmental Impact Assessment directive (now, having been amended, Directive 2011/92/EU, in turn amended by Directive 2014/52/EU), which already granted access to NGOs. 
Especially after the Paris Agreement (2015, entered into force in 2016, where states accepted to take climate action on the basis of equity and to keep global temperature increase below 1.5 degrees Celsius, and no more than 2 degrees), and the initiative toward a Global Pact for the Environment, or GPE (2017), 32 access to justice is going to become a generator of further substantive environmental protection, meaning that it won't be just a way to make "existing" substantive rights justiciable. Of particular value and impact in the environmental legal setting is the progress made through national litigation. In a diversity of cases, claimants have asked courts to accept their (unprecedented) standing, have challenged traditional interpretations of law, and prompted courts to rethink the issue in light of the many converging legal documents interweaving national and international norms, in such a way as to disclose quite new scenarios. Starting from a wider and deeper implementation of the Aarhus Convention, access to justice becomes a powerful channel for policymaking, information, and participation. Indeed, in many cases it not only allows existing substantive rights to be vindicated and gain further purchase in environmental matters (this applies, for example, to the right to life, health, and property in the ECHR), but it also sets the stage for the new sensibility, which is slowly leading to the much-awaited recognition of a newly forged substantive right to a healthy environment. ${ }^{33}$ That seems indispensable because, among other reasons, it helps shorten the causal link between greenhouse gas emissions and emitters, on the one hand, and human rights breaches, on the other, while a weaker protection, as by "greening" other first- or secondgeneration human rights, is insufficient to shield fundamental rights from climate change. That has a further advantage in accessing justice: As Alan Boyle $(2012,641)$ wrote, "clarifying the existence of such a right would entail giving greater weight to the global public interest in protecting the environment and promoting sustainable development." 34

After Dutch citizens represented by the Urgenda Foundation were able to access justice before The Hague District Court (2015) ${ }^{35}$ and obtain a positive decision on their claim (requesting that the Dutch government adopt a number of measures to mitigate climate change), several important cases were brought to court, and by seeking standing, i.e., access to justice, they in fact were also pleading for the recognition of otherwise immaterial environmental rights. Famously, in 2016, in Juliana v. United States, also known as the "Kids' Climate Case," ruling against a motion for dismissal

32 Launched as a draft, the GPE was brought to the United Nations General Assembly, which on May 10, 2018, committed to it under Resolution 72/277, "Towards a Global Pact for the Environment" (UNGA 2018a). Notably, the GPE starts out at Article 1 (Right to an Ecologically Sound Environment) with the following declaration: "Every person has the right to live in an ecologically sound environment adequate for their health, well-being, dignity, culture and fulfilment."

33 In a 2018 report (UNGA 2018b), John H. Knox, independent special rapporteur appointed by the Human Rights Council in 2012, wrote that we need to recognize as a coherent result of the work of human rights bodies a right to safe clean healthy and sustainable environment, though this is admittedly something that some national and regional documents or courts had explicitly or implicitly recognised before.

34 And, on the other side, "NGOs are already entitled to protect the human rights of victims of violations, and there is no need to extend their standing for that purpose. Extending their standing in environmental matters makes sense only if the public interest in the environment itself is to be protected - that is the point of Aarhus" (Boyle 2012, 641; see also 626).

35 Details at https://www.urgenda.nl/en/themas/climate-case/. 
by the federal government, ${ }^{36}$ Judge Ann Aiken not only accepted the case, but in order to confirm the right to access justice, she firstly remarked that plaintiffs have demonstrated received injuries, and then, acknowledging that damages are reaching an unsustainable catastrophic level, articulated a new right to a "climate system capable of sustaining human life," stating that "defendants' actions and inactionswhether or not they violate any specific statutory duty-have so profoundly damaged our home planet that they threaten plaintiffs' fundamental constitutional rights to life and liberty." ${ }^{\prime 37}$

Most notable is the telling evolution in litigation under Article 26 of the American Convention on Human Rights (ACHR) concerning the duties of states to carry out progressive development towards the "full realization of the rights implicit in the economic, social, educational, scientific, and cultural standards recognized in the Charter of the Organization of American States." ${ }^{\prime 38}$ In its own words, the InterAmerican Court of Human Rights found that the Argentine "State is responsible for the violation of the right to take part in cultural life as this relates to cultural identity, a healthy environment, adequate food and water, established in Article 26 of the American Convention on Human Rights, in relation to Article 1(1) of this instrument, to the detriment of [...] 132 indigenous communities." 39 The Lhaka Honhat (Our Land) Association of Indigenous Communities claimed that Argentina had infringed their rights to cultural identity, adequate food, and a healthy environment,

36 The bases for the dismissal are so summarized in the decision: "They contend plaintiffs' claims must be dismissed for lack of jurisdiction because the case presents non-justiciable political questions, plaintiffs lack standing to sue, and federal public trust claims cannot be asserted against the federal government. They further argue plaintiffs have failed to state a claim on which relief can be granted." Juliana v. United States, 217 F. Supp. 3d 1224, 1236 (D. Or. 2016).

37 Juliana, F. Supp. 3d, at 1261. Other cases are relevant. For example, of the same significance, both for access to justice and for environmental law, is the so-called People's Climate Case, which was accepted by the CJEU, General Court, and filed in May 2018 by ten families and the Sáminourra Sami Youth Association in Sweden (see "Case T-330/18: Action Brought on 23 May 2018-Carvalho and Others v Parliament and Council," OJ C 285, 13.8.2018, pp. 34-6). Here the plaintiffs claim that the EU's existing 2030 climate target to reduce domestic greenhouse gas emissions by at least 40 percent by 2030 (as compared to 1990 levels) is inadequate with respect to the real need to prevent dangerous climate change and insufficient to protect their fundamental rights to life, health, occupation, and property.

38 "Progressive Development: The States Parties undertake to adopt measures, both internally and through international cooperation, especially those of an economic and technical nature, with a view to achieving progressively, by legislation or other appropriate means, the full realization of the rights implicit in the economic, social, educational, scientific, and cultural standards set forth in the Charter of the Organization of American States as amended by the Protocol of Buenos Aires" (Art. 26 ACHR).

${ }^{39}$ Inter-American Court of Human Rights, Case of the Indigenous Communities of the Lhaka Honhat Association (Our Land) v. Argentina: Merits, Reparations and Costs. Judgment of February 6, 2020, Series C No. 400, par. 370(3). The Spanish original: "El Estado es responsable por la violación a los derechos a participar en la vida cultural, en lo atinente a la identidad cultural, al medio ambiente sano, a la alimentación adecuada y al agua, establecidos en el artículo 26 de la Convención Americana sobre Derechos Humanos, en relación con el artículo 1.1 del mismo tratado, en perjuicio de las 132 comunidades indígenas." Corte Interamericana de Derechos Humanos, Caso Comunidades Indígenas Miembros de la Asociación Lhaka Honhat (Nuestra Tierra) vs. Argentina: Fondo, Reparaciones y Costas. Sentencia de 6 de febrero de 2020. Serie C No. 400, par. 370(3). 
considered "as autonomous rights that they understood were contained in Article 26 of the Convention." 40

Evidently, the point of the justiciability of economic social and cultural rights is here coupled with the disclosing of the "implicit," which by way of interpretation adjudicates the claim on the basis of the implied and autonomous environmental right as well. Here, for the first time, the Inter-American Court decided a case based on an advisory opinion it had previously issued in 2017 on the right to a healthy environment. ${ }^{41}$ As the Court points out in its 2020 judgment, referring to Paragraph 57 of the 2017 opinion: "This Court has already stated that the right to a healthy environment 'must be considered one of the rights [...] protected by Article 26 of the American Convention [ACHR],' given the obligation of the State to ensure 'integral development for their peoples,' as revealed by Articles 30, 31, 33 and 34 of the Charter [of the Organization of American States]." 42

The mentioned events revolve around "dynamic" considerations using the embedded potentiality of legal wording like "integral development," "progressive development," and "implicit rights." As should be clear by now, the role of access to justice-especially in cases such as the foregoing, so deeply connected to environmental protection-becomes that of triggering such a generative bodying forth of substantive rights of previously uncertain import or even unintended existence.

Finally, and beyond such a generative potential, this is testament to the dynamic character of access to justice as well. Its evolution, in the many areas in which it unfolds, and the concretization of evolving requirements of effectivity and fairness, bears out the peculiar logic of "accessing" as an ongoing enterprise whose transformations and adaptations are inherent in the foundational nature of a "right" that is the necessary implication of the very existence of law (and justice).

Sant'Anna School of Advanced Studies
Piazza Martiri della Libertà 33
56127 Pisa
Italy
Email: g.palombella@santannapisa.it

40 Inter-American Court of Human Rights, Case of the Indigenous Communities of the Lhaka Honhat Association (n. 39), par. 186. The Spanish original: "como derechos autónomos, que entendieron contenidos en el artículo 26 de la Convención." Corte Interamericana de Derechos Humanos, Caso Comunidades Indígenas Asociación Lhaka Honhat (n. 39), par. 186.

${ }^{41}$ Inter-American Court of Human Rights, Advisory Opinion OC-23/17 of November 15, 2017, Requested by the Republic of Colombia: The Environment and Human Rights. Series A No. 23. Corte Interamericana de Derechos Humanos, Opinión Consultiva OC-23/17 de 15 de Noviembre de 2017, Solicitada por la República de Colombia: Medio Ambiente y Derechos Humanos. Serie A No. 23.

${ }_{42}$ Inter-American Court of Human Rights, Case of the Indigenous Communities of the Lhaka Honhat Association (n. 39), par. 202 (italics in the original). The Spanish original: "Este Tribunal ya ha manifestado que el derecho a un medio ambiente sano 'debe considerarse incluido entre los derechos [...] protegidos por el artículo 26 de la Convención Americana,' dada la obligación de los Estados de alcanzar el 'desarrollo integral' de sus pueblos, que surge de los artículos 30, 31, 33 y 34 de la Carta." Corte Interamericana de Derechos Humanos, Caso Comunidades Indígenas Asociación Lhaka Honhat (n. 39), par. 202 (italics in the original). 


\section{References}

Barbier de la Serre, E. 2006. Procedural Justice in the European Community CaseLaw concerning the Rights of the Defence: Essentialist and Instrumentalist Trends. European Public Law 12(2): 225-50.

Boyle, A. 2012. Human Rights and the Environment: Where Next? European Journal of International Law 23: 613-42. https://doi.org/10.1093/ejil/chs054.

Cancado Trindade, A. 2011. The Access of Individuals to International Justice. Oxford: Oxford University Press.

Cappelletti, M., and B. Garth. 1978. Access to Justice: The Newest Wave in the Worldwide Movement to Make Rights Effective. Buffalo Law Review 27: 181-292, https:/ / www.repository.law.indiana.edu/facpub/1142.

Francioni, F. 2007. The Rights of Access to Justice under Customary International Law. In Access to Justice as a Human Right. Ed. F. Francioni, 1-56. Oxford: Oxford University Press.

Fuller, L. 1969. The Morality of Law. New Haven, CT: Yale University Press.

Halmai, G. 2017. The Early Retirement Age of the Hungarian Judges. In EU Law Stories: Contextual and Critical Histories of European Jurisprudence. Ed. F. Nicola and B. Davies, 471-88. Cambridge: Cambridge University Press.

Hart, H. L. A. 1982. Legal Rights. In Essays on Bentham: Jurisprudence and Political Philosophy, 162-93. Oxford: Oxford University Press.

Jones, J. 2012. Human Dignity in the EU Charter of Fundamental Rights and Its Interpretation before the European Court of Justice. Liverpool Law Review 33: 281-300.

Kant, I. 1996. Metaphysical First Principles of the Doctrine of Right. In The Metaphysics of Morals. Trans. M. Gergor, 33-177. Cambridge: Cambridge University Press.

Krämer, L. 2015. The EU Courts and Access to Environmental Justice. In Environmental Law Dimensions of Human Rights. Ed. B. Boer, 107-33. Oxford: Oxford University Press.

Krygier, M. 2009. The Rule of Law: Legality, Teleology, Sociology. In Relocating the Rule of Law. Ed. G. Palombella and N. Walker, 45-70. Oxford: Hart Publishing.

Michelman, F. I. 1977. Formal and Associational Aims in Procedural Due Process. In Nomos XVIII: Due Process. Ed. J. R. Pennock and J. W. Chapman, 126-71. New York: New York University Press.

Palombella, G. 2016. German War Crimes and the Rule of International Law. Journal of International Criminal Justice 14(3): 607-13. https:/ / doi.org/10.1093/jicj/mqv070.

Palombella, G. 2018. Illiberal, Democratic and Non-arbitrary? Epicentre and Circumstances of a Rule of Law Crisis. Hague Journal on the Rule of Law 10(1): 5-19. https: / /doi.org/10.1007/s40803-017-0059-9.

Palombella, G. 2019a. Theory, Realities, and Promises of Inter-legality: A Manifesto. Chap. 16 in The Challenge of Inter-legality. Ed. J. Klabbers and G. Palombella. Cambridge: Cambridge University Press.

Palombella, G. 2019b. Two Threats to the Rule of Law: Legal and Epistemic. Hague Journal on the Rule of Law 11(2-3): 383-88. https://doi.org/10.1007/s40803-01900093-3.

Raz, J. 1979. The Rule of Law and Its Virtue. Chap. 11 in The Authority of Law: Essays on Law and Morality. Oxford: Clarendon Press.

Raz, J. 1986. The Morality of Freedom. Oxford: Clarendon Press. 
Roesler, S. M. 2012. The Nature of the Environmental Right to Know. Ecology Law Quarterly 39(4): 989-1048.

Schoukens, H. 2015. Access to Justice in Environmental Cases after the Rulings of the Court of Justice of 13 January 2015: Kafka Revisited? Utrecht Journal of International and European Law 31(81): 46-67.

Summers, R. 1974. Evaluating and Improving Legal Processes-a Plea for Process Values. Cornell Law Review 60(1): 1-52.

UNGA (UN General Assembly). 2018a. Towards a Global Pact for the Environment. Resolution adopted on May 10, 2018, 72nd session, agenda item 14. UN doc A/ RES/72/277. https:/ / digitallibrary.un.org/record/1617171?ln=en.

UNGA (UN General Assembly). 2018b. Report of the Special Rapporteur on the Issue of Human Rights Obligations Relating to the Enjoyment of a Safe, Clean, Healthy and Sustainable Environment, 73rd session (July 19, 2018). UN doc A/73/188. https: / / digitallibrary.un.org/record/1639368? $\ln =\mathrm{en}$. 